\title{
CLASS INEQUALITY AND CAPITAL ACCUMULATION IN BRAZIL, 1992-2013
}

Pedro Mendes Loureiro-University of Cambridge (CLAS-POLIS)

\begin{abstract}
This article explores the patterns of class inequality and capital accumulation in Brazil, showing the drivers and limits of the decline in inequality that occurred during the Workers' Party governments. It proposes that minimum wage hikes and greater social security changed the demand pattern and kick-started a cumulative causation process. Growth and redistribution thus reinforced each other for a period, and then spelled their own limits. As growth accelerated in the 2000s, a Gini decomposition indicates that class inequality decreased, but confined to changes between workers - capitalist income and social stratification were preserved. This also endogenously led to a regressive structural change, as low-productivity, labour-intensive services grew and international trade patterns worsened. This created a medium-term dependence on commodity prices for balance-of-trade solvency, and heightened cost-push inflation, which could not be overcome under the limited policy framework in place. The constrained basis for reducing inequality and the regressive structural change underscore that developmental strategies requires broad, multi-dimensional inequality-reducing measures and an encompassing catching-up project.
\end{abstract}

Key words: inequality, class analysis, structural change, development, Brazil.

JEL: O10; D63; L16.

Acknowledgements: the author is grateful for the contribution several colleagues and friends made to this article, and would especially like to thank Alfredo Saad-Filho, Claudio Amitrano, Ítalo Pedrosa, Leonardo Lins and Pauline Debanes, as well as the members of the 2017 EAEPE-Simon Young Scholar Prize committee for awarding it the prize which has stimulated the development of this research. The usual disclaimers apply. The author also thanks CAPES for the grant BEX 0840/14-9. 


\section{INTRODUCTION}

Brazil, alongside other countries of the Latin American 'Pink Tide', underwent a growth and redistribution process during the 2000s, after two 'lost decades' of economic stagnation and income polarisation. Seemingly flying against the country's entrenched patterns of exclusionary, pro-rich growth, output grew as social indicators improved during the centre-left Workers' Party (PT, Partido dos Trabalhadores) administrations. Under the permissive conditions the 'commodities supercycle' and high international liquidity provided, euphoria reigned as domestic and international commentators exclaimed Brazil showed the path ahead for middle-income countries. A few years later, in 2019 none of these conditions held any longer: Brazil was in a critical economic and social crisis, unemployment had risen massively, commodity prices had fallen, and former president Dilma Rousseff of the PT had been impeached and later substituted by the far-right politician Jair Bolsonaro, with few centre-left governments still standing in Latin America. Optimism had been unfounded, the positive cycle short-lived, and no real prospects of inclusionary growth were to be found.

What explains this volte-face, the incapacity of Brazil embarking on a sustained process of development? What was the connection between the two phases: did the boom period lay the seeds for its own end, or was the downturn an external event that does not speak to insufficiencies of the former? On the undeniably nuanced answer to these questions rest major issues for understanding the contemporary possibilities for development, which extend much beyond the Brazilian case. Although historically specific, the key mechanisms behind the growth and redistribution episode - structural change, the country's insertion into the world market, social security and labour market policies-are widely relevant for other experiences. Brazil's advances and limits during the 2000s can thus provide lessons for other middle-income countries about how, to which extent, and under which circumstances it is possible to pursue pro-poor, equality-driven growth agendas.

This article hence seeks to discern the drivers and the limitations of growth and redistribution in Brazil, seen as interconnected phenomena, focusing on the decrease of income inequality between 2003 and 2013. It is organised as follows. The second section presents the main argument, which is empirically 
substantiated in the following ones. It argues there was a cumulative causation process explaining both growth and redistribution, driven by rising minimum wages (MWs) and social-security transfers. These policies increased low incomes and hence shifted the pattern of demand towards wage goods and services, heating the low-skilled segment of the labour market, reducing inequality and thus reinitiating the cycle. In doing so, this process brought about a regressive structural change - the rise of low-productivity, labour-intensive sectors - and inflationary pressures that would become major medium-term constraints. The third section explores the growth pattern of the economy, identifying the drivers of growth, their sectoral dimension and their implications for income distribution. The fourth section analyses the evolution of inequality through a decomposition of the Gini index (known as the Analysis of Gini, ANOGI), applied to a typology of class positions based on household surveys. It shows how there were indeed gains, but restricted to shifts between workers which preserved capital income. The fifth section explores how these developments modified the economy's constraints and eventually led to a conundrum. The two main points are, first, that the regressive structural change deteriorated the country's insertion into the world market. Second, wage gains in services, the motor of both growth and redistribution, led to escalating cost-push inflation. It is shown that the policy framework in place, with low public investment, high interest rates, an overvalued exchange rate, and a poorly planned industrial policy, could not overcome this conundrum. The sixth section concludes.

\section{GROWTH, REDISTRIBUTION AND REgRESSIVE STRUCTURAL CHANGE IN A CUMULATIVE}

\section{CAUSATION FRAMEWORK}

The main argument of this article is that the PT implemented key policies that delivered growth and improved social standards between 2003 and 2013, particularly lower income inequality and poverty, but fell short of securing conditions that would allow the process to maintain itself. On the contrary, it was dynamically unsustainable, as it endogenously transformed the productive structure in ways that heightened two long-standing constraints of the economy. Specifically, it worsened the country's international trade patterns and produced inflationary pressures that could not be overcome in the prevailing policy mix. Finally, to overcome these constraints without sacrificing growth and 
redistribution, deeper-reaching, transformative strategies were required, which would inevitably confront established interests.

Both the growth and redistribution phase and the constraints it generated are explained through a cumulative causation mechanism, illustrated in Figure 1. The explanation for the ascendant phase builds upon an argument Rugitsky (2017) proposed, according to which the 2000s was the obverse of the 'economic miracle' of 1969-1973 period. This previous episode, amidst the repression of the military dictatorship, was marked by fast growth and income concentration. As the domestic production of high value-added goods picked up, scarce high-skilled labour was employed amidst generalised social and labour repression, thus concentrating wages and raising anew the demand for such goods, closing the circle.

\section{[FIGURE 1]}

The mechanisms of the 'inside-out miracle' are presented in the upper-left circle of Figure 1. Incomeboosting policies were exogenous drivers that, in changing the patterns of demand, initiated a series of market mechanisms stimulating growth and redistribution. Three policies were central to this: MW hikes, the conditional cash transfer (CCT) programme Programa Bolsa Familia (PBF), and higher social-security transfers (pensions and old-age benefits). With bottom-incomes rising, the demand for wage goods increased and stimulated employment in these sectors, intensive in low-skilled labour and with high labour-shares of income. This heated the labour market, driving further gains for low-waged workers plus labour formalisation — tantamount to reducing inequality—and reinitiating the cycle. Growth and redistribution were thus essentially linked, as the income-boosting policies and the market mechanisms they initiated stood behind both their dynamics.

In bringing about growth and redistribution, the 'inside-out miracle' also endogenously heightened two medium-term constraints, represented in the bottom-right circle of Figure 1. The wage-goods sectors not only employed low-skilled labour, which redistributed income. They were also mostly lowproductivity personal services subject to cost-push inflation, the growth of which implied a regressive structural change. This decreased the competitiveness of the economy, as it prevented overall 
productivity gains and forestalled the development of import-substituting or export-orientated sectors, whilst there was no consistent industrial policy in place to counterbalance these factors. The results were a more precarious export bill heavy in resource-based and primary products, on which the country possessed static comparative advantages, and a rigid imports bill concentrated in intermediate goods needed to maintain output. And, as wage gains in these very sectors drove growth and redistribution, they also produced cost-push inflation. It thus obtains that the growth and redistribution process was also inherently inflationary, and would require countervailing measures to ease this constraint.

The central policy dilemma was the exchange rate. Overvaluing it through high interest rates to attract foreign capital — as occurred—would ease inflation, but at the cost of raising already-escalating current-account deficits. This eventually led to a conundrum, it becoming impossible to balance growth, falling inequality, monetary stability and balance-of-trade solvency under an ongoing regressive structural change with an overvalued currency. To overcome this, deeper sources of inequality — such as the tax system and capital income-would have to be addressed and bolder industrial policies put in place. ${ }^{1}$ In other words, the policy framework had to be overhauled. The text now empirically substantiates this argument.

3. THE PATTERN OF ACCUMULATION: DOMESTIC-LED GROWTH AND REGRESSIVE STRUCTURAL CHANGE

\subsection{Domestic-driven growth and falling income inequality}

Brazil experienced a growth surge from 2003 to 2013, roughly at the same speed as other Latin American and Caribbean (LAC) countries: GDP per capita in Brazil was 33.5\% higher in 2013 than it was in 2002, whereas in the whole region it had grown by $30.0 \%$ (constant 2011 international dollars, World Bank Open Data). Brazil thereafter entered a deep crisis whilst the region 'just' stagnated, as GDP per capita decreased by $8.6 \%$ from 2013 until 2017 in Brazil and by $0.6 \%$ in LAC. 
Brazil's growth process can be divided into two phases (see Table 1). The initial uptick was caused by higher commodity export prices, raising the real growth rate of output from $1.1 \%$, in 2003 , to $5.8 \%$ in 2004. This was later succeeded by an internally driven process based on income redistribution, public investment and induced private investment. This led to an average growth rate of $4.4 \%$ from 2006 to 2011, after which it steadily declined, as output decreased by 3.6\% in 2015 (data from Ipeadata).

\section{[TABLE 1]}

\section{[FIGURE 2]}

As shown in Table 1, between 2003 and 2005 output growth was driven mainly by the autonomous rise of exports, which responded for $42.7 \%$ of the rise in aggregate demand. This was the first component to rise substantially (see Figure 2), contributing with 1.3 points of total growth in 2003, when both investment and private consumption were falling. This can be attributed to the rise of Chinese demand for commodities (Medeiros and Cintra 2015), which was met with growing volumes of exports amidst also rising prices_-volumes increased $63.7 \%$ between 2001 and 2005, and prices $24.2 \%$ (Ipeadata).

This fortuitous uptick in demand initiated a growth cycle whose characteristics would soon change: driven by household consumption and investment, in the 2006-2013 period output grew at an average rate of 3.9\% per year. Exports, between 2006 and 2013, contributed with a measly 5.5\% of total GDP growth. They were superseded by private consumption $(59.8 \%)$ and investment $(22.7 \%)$, with government consumption also playing a role $(11.8 \%)$. Differently from the preceding period, this was clearly a domestic-led growth cycle. Exports and international credit also played a role, however, as they displaced the balance-of-payments constraint: foreign currency availability rose from approximately 50 billion USD in 2005 to 350 billion in 2011 (data from BCB), providing an important safety cushion.

The key to understand the dynamics of this cycle, in light of the small contribution of government consumption and exports, lies in the determinants of household consumption and investment, as well 
as in the relation between the several components. In other words, it is a matter of identifying the autonomous drivers of household consumption and investment, and then how they led to endogenous responses that cemented a growth cycle. This will be complemented below through the sectoral pattern of growth and, in the next section, through a deeper analysis of income redistribution.

Regarding household consumption, there were four main elements: rising MWs and increased socialsecurity transfers, as autonomous drivers, and growing indebtedness and labour market participation, as partially endogenous responses. The real MW grew upwards of 70\% from 2003 to 2013, and 56\% between 2005 and 2013 (Ipeadata). ${ }^{2}$ This had a strong impact on the labour market as approximately $54 \%$ of all employees received between one and two MWs in 2005 (PNAD/IBGE). Furthermore, this did not increase non-compliance, as the share of employees receiving less than one MW fell from $34 \%$ to $27 \%$ between 2005 and $2013 .^{3}$ Given the higher propensity to consume amongst lower-income groups, this translated almost entirely into greater demand.

A rising MW had effects beyond the labour market, as it indexes several social-security benefits and state pensions. Orair and Gobetti (2010) indicate that, between 2002 and 2010, government transfers to households-comprising state pensions, social-security and unemployment benefits, CCTs and similar programmes - rose by almost 2 p.p. of GDP. Importantly, almost $40 \%$ of this increase can be attributed to rising MWs. Therefore, higher values for benefits, increased coverage and the creation of new programmes combined to raise the income of the poorer sections of the population, autonomously raising demand.

Indebtedness rose considerably during this period, from $21.7 \%$ of household income in December 2005 to $45.0 \%$ in December 2013 (or from 21.1\% to 29.4\% excluding mortgages), after which it stagnated or decreased (data from BCB). This comprised both greater debt for households already in the financial sector as well as, importantly, the extension of credit instruments to new consumers. Between 2005 and 2010, the share of households with credit cards increased from $15 \%$ to $25 \%$ for those with an average income up to $3 \mathrm{MWs}$, and from $30 \%$ to $43 \%$ for average incomes between 3 and 5 MWs (Lavinas 2015). 
Finally, investment was structurally curtailed during the whole period due to the policy frameworks in place, the so-called 'macroeconomic tripod' and later the 'new economic matrix'. The tripod, introduced in 1999, comprised a floating exchange rate, primary government surpluses and inflationtargeting, with three key implications (Morais and Saad-Filho 2011). First, the primary interest rate was the key instrument to combat inflation, which had to be kept inordinately high as the efficacy of monetary policy in Brazil was strongly limited (for details, see Barboza 2015). Consequently, the resulting real market interest rates in Brazil from 2003 until 2013 were on average 35.3\% per annum, the second-highest in the world (out of 170 countries, only below Zimbabwe) and nearly five times the country-average for LAC, which was 7.5\% (World Bank Open Data).

Second, the currency was kept overvalued, as the key channel for combatting inflation with high interest rates was attracting foreign capital to appreciate the real. The Central Bank thus had an 'appreciation bias' in its management of the (dirty) floating exchange rate (Kaltenbrunner and Painceira 2017). As a result, the nominal exchange rate appreciated almost continuously between 2003 and 2011, going from a year-average of 3.08 BRL/USD to 1.67 (Ipeadata), reducing the competitiveness of domestic tradables and curtailing investment.

Third, public investment was held back by the need of maintaining primary surpluses. This is key, given there is a strongly complimentary relationship between public and private investment in the country (Santos et al. 2016b, Serrano and Summa 2015). In this vein, total public gross fixed capital formation, including state-owned enterprises (SOEs), grew at an annualised real rate of $0.4 \%$ per year from 2003 until 2006, rising to $17.0 \%$ from 2007 until 2010, before falling to $-1.0 \%$ from 2011 until 2013 (calculated based on data presented in Orair 2016: 16). This revival of public investment during Lula's second presidential term (2007-2010) was delivered through initiatives such as the Growth Acceleration Programme (Programa de Aceleração do Crescimento-PAC), which offered a somewhat greater role for state-directed investment (Morais and Saad-Filho 2011), but it was limited in two ways. First, the average rate of public investment to GDP during this period was of 3.7\%, peaking at $4.6 \%$ in 2010 , which is substantially low from a historical perspective: between 1958 and 
1990 it was above $5.0 \%$ for every single year, and frequently between $6.0 \%$ and $7.0 \%$ (Orair 2016: 13).

The second limitation of the public investment spurt of 2007-2010 was, precisely, its short-lived nature. In 2011, President Dilma Rousseff put in place the 'new economic matrix', which, given its similarities to the demands of the country's largest business association-Federação das Indútrias do Estado de São Paulo, FIESP — has also been called the 'FIESP agenda' (Carvalho 2018). For explaining (the decline of) growth and investment from 2011 onwards, its key dimension was reducing direct public investment in lieu of subsidies and tax rebates for private companies, hoping the latter would convert this into investment. Thus, public investment decreased, as shown above, whilst subsidies increased at an annualised real rate of 26.7\% from 2011 until 2014 (Gobetti and Orair 2015: 435). Whilst this is likely to have secured high profit margins of companies, it did not lead to private investment and it had a small impact on growth, as the economic multipliers of subsidies are much smaller than that of public investment (Carvalho 2018, Serrano and Summa 2015). As a result of these structural and policy constraints, total gross capital formation as a percentage of GDP in Brazil from 2003 until 2013 was on average 1.2 p.p. below that of LAC as whole, which is already below that of other developing regions of the world (it surpassed the region's ratio only in 2010, by 0.3 p.p.; World Bank Open Data).

\subsection{The sectoral dimension of the cumulative causation of growth, redistribution and regressive structural change}

Having established that growth was domestically driven, with household consumption playing the leading role, this subsection explores how the autonomous drivers of demand (rising MWs, credit and social-security transfers) changed the patterns of demand and kick-started a cumulative causation process connecting growth, distribution and (regressive) structural change. National accounts data show that, between 2003 and 2013, total employment increased by 18.8 million. Of the 51 activities discriminated in the national accounts, 13 increased their employment by more than 500 thousand. Ten 
of these were private, and responded for $82.1 \%$ of the net employment generated. The analysis will thus consider these ten activities, listed in Table 2.

\section{[TABLE 2]}

First, only one sector (machinery and equipment) had an average wage substantially above the overall mean wage (1.63 times), and its contribution to job creation was modest, at $2.8 \%$ of the total. Five other sectors were close to average wages, and four substantially below. Taken together, the relative average wage of these ten sectors was 0.78 . This confirms the first link, namely that employment grew mostly in low-paid sectors. As shown below, it also explains the higher clustering of the income of low-skilled workers between one and two MWs.

Second, with the exception of services provided to businesses and machinery and equipment, the other sectors were services, the demand for which came mostly from workers. Food and beverages, sales, lodging, services provided to families and for-profit health and education stood out, indicating higher demand for wage-goods. Construction can be taken along the same lines, given the importance of the popular housing programme Minha casa, minha vida (My house, my life), which, between 2009 and 2014, delivered about 2 million housing units according to official data (for an analysis of the programme and Brazilian growth dynamics, see Krause, Balbim and Lima Neto 2013). This thus confirms the second link, that the driver of demand for domestic output was the growth of income at the bottom of the distribution.

Third, these were mostly low-productivity sectors, orientated to the domestic market. Together, the labour productivity of these ten sectors was $23 \%$ below economy-wide average in 2013 , and their overall productivity gains were close to the mean. Only the labour productivity of machinery and equipment was somewhat above, at 1.3 the average in 2013 , but marred by a decrease of $\mathrm{R} \$ 10,700$ per worker per year (in constant 2003 reais) over the analysed period. Which is to say, besides the economy shifting to overall low-productivity sectors, its supposedly dynamic sectors were furthermore lagging behind, forestalling competitiveness gains. Therefore, the structural change initiated by the 
cumulative causation mechanism was regressive, in that it spurred low-productivity services sectors, incapable of driving dynamic productivity gains for the economy.

A point that connects these three dimensions regards the functional distribution of income in these sectors. The wage-share of the whole economy increased from 0.449 to 0.506 during this period, which indicates that the pattern of growth both stimulated the wage mass and relied on it as the main dynamic driver of demand..$^{5}$ This increase was, furthermore, in large part determined by changes in the productive structure of the economy: Martins (2017) uses data from the National Accounts and, by means of a shift-share method applied to the 2000-2013 period, estimates that the growth of labourintensive sectors was twice as important as the intra-sector increase of the wage-share. Therefore, labour-intensive sectors were the drivers of growth and structural change, further highlighting the technologically regressive character of the latter ${ }^{6}$

In sum, the sectoral dimension allows a deeper look into how the growth and redistribution process became, for a while, self-propelling. Aggregate data had shown how household consumption, stimulated by rising MWs and government transfers, were the main dynamic elements of the cycle. The sectoral pattern of growth then indicated how demand was concentrated at wage-goods, particularly services, aimed at workers climbing the bottom of the income ladder. These goods were supplied domestically, in sectors with below-average wages and labour productivity, but aboveaverage wage-shares of value added. This heated the labour market for low-skilled occupations, increasing low-skilled wages and labour formalisation, which added fresh demand for these goods and services. The text now explores how this fed into income redistribution.

\section{Class inequality in Brazil}

High levels of inequality are a perennial feature of Brazil, which has always had some of the most unequal income distributions of the world. During the early 2000s and until recently, however, there was an inflection in this trend, summarised in the decrease of the Gini coefficient of per capita household income from 0.596, in 2001, to 0.527, in 2013 (according to data from the National 
Household Sampling Survey-PNAD). This de-concentration was all the more striking since inequality was rising in most of the world (Simson 2018). It was, however, a fairly average decrease for LAC during this period: the mean decrease in the region, from 2002 until 2013, was of 0.064 (data from PovcalNet, World Bank). ${ }^{7}$

It is now well established that labour market-related developments were key to the equalisation of income, followed by the extension of state pensions and higher government transfers, particularly through PBF. Using income-source decompositions, Hoffmann and Oliveira (2014) estimated that these three dimensions responded, respectively, for about $55 \%, 22 \%$ and $17 \%$ of the decrease of the Gini coefficient between 2003 and $2011 .^{8}$ Once again, this was a broadly common pattern of drivers throughout LAC: Azevedo et al. (2013), for example, studying 14 countries during the 2000s, found that on average $55 \%$ of the decline in inequality was due to changes in the distribution of labour-market income, with only four countries deviating substantially from this value, and $30 \%$ due to government transfers and pensions, with little country-level deviation.

With the recent release of tax returns data, however, inequality proved much higher than in household surveys, and top incomes more stable over time. These data suggest that the $1 \%$ appropriated about $25 \%$ of national income between 2006 and 2011 in Brazil, and the $0.1 \%$ approximately $10 \%$ (Medeiros and Castro 2018). Furthermore, capital-related income (profits, interest...) played a major and increasing role at the top: restricting the sample to the $10 \%$ richest households, it responded for $26 \%$ of the inequality in 2006 , and $39 \%$ in 2012.

To explore the class dimension of inequality and understand its relation to the pattern of accumulation, this article develops a lean typology of class positions based on the works of Wright (2000) and applies it to data from household surveys. The typology captures the essential attributes of the Brazilian class structure, subject to data availability, whilst remaining sufficiently parsimonious to allow for detailed analysis of individual fractions. This led to a definition of eight positions, attentive to differences amongst employers and amongst workers, and including pensioners and the unemployed. ${ }^{9}$ Informality, 
a major characteristic of the Brazilian labour market, is also incorporated (see the Appendix for details).

\subsection{The ANOGI method}

The analysis of inequality employs the ANOGI method, briefly presented here. For a more detailed exposition, please consult Yitzhaki and Schechtman (2013). This decomposition is chosen because it produces terms with clear analytical interpretation, differently from those that lead to a residual without clear meaning (e.g. Pyatt 1976). Furthermore, it centrally takes into account stratification and its inverse, overlapping between the groups. This is an important dimension in studying class relations, as it indicates the extent to which the groups occupy the same space in the income distribution.

The overall Gini index, $G$, can be decomposed into two components:

$$
G=G_{W O}+G_{B}
$$

where $G_{W O}$ is the within-groups Gini coefficient and $G_{B}$ is the between-groups Gini. The terms can be described as follows:

1. $G_{W O}$ : within-groups inequality, it is an income-share-weighted average of Gini coefficients calculated over members of each group, adjusted for overlapping. It varies between 0 , when the members of all groups receive the group's mean income, and $G$, when all groups have got the same mean income or mean rank;

2. $G_{B}$ : between-groups inequality, adjusted for overlapping. It varies between 0 , when all groups have got the same mean income or rank, and $G$, when the members of all groups receive the group's mean income. ${ }^{10}$

Furthermore, the method produces a measure of stratification across groups, $G_{B} / G_{B P}$. By comparing $G_{B}$ to the 'pure' between-groups component that disregards overlapping, $G_{B P}$, it can be seen the extent to which overlapping reduces between-groups inequality. 
The decomposition can also be expressed as a summation over the groups:

$$
G=\sum_{h=1}^{k} p_{h}\left[\eta_{h} G_{h} O_{h}+2\left(\eta_{h}-1\right)\left(F_{h}-0.5\right)\right]
$$

where $p_{h}$ is the population-share of group $h, \eta_{h}$ its relative income, $O_{h}$ its overlapping index, and $F_{h}$ the mean rank of the group members in the overall distribution. $O_{h}$ is a measure of how much are the distributions of all other groups contained in that of $h$, and varies between $p_{h}$, when the group is a perfect stratum (i.e. no other group shares its income range) and 2, when its income is much more spread than that of the overall distribution. An index of 1 indicates a group as spread as the overall distribution. Expression (2) is used to explore which characteristics of the income distribution drove the observed changes, as it allows not only a look into which groups changed their profile but also which aspects of the latter were the most relevant.

\subsection{A class perspective on Brazilian inequality}

This sub-section explores the patterns of inequality in Brazil, focusing on their class dimension. It is shown how within-class inequality fell over all the period, whereas between-class inequality increased during the 1990s and fell in the following decade. This latter process was restricted, however, to changes between different categories of workers, with the position of capital vis-à-vis labour remaining unchanged.

\section{[FIGURE 3]}

Figure 3 reports the breakdown of inequality into within- and between-groups components for the whole period. A first observation, which vindicates the framework employed, is that between-class inequality was a relevant phenomenon throughout, as it accounted for between $30 \%$ and $35 \%$ of total inequality. Likewise, income was clearly stratified across classes, given that overlapping reduced the pure between-groups Gini by only about $40 \% .^{11}$ 
The overall movements of inequality, with a slight rise during the beginning of the period followed by stagnation and then a consistent decrease, hide different class dimensions. Whilst within-class inequality decreased by between one and two points during the 1990s, depending on the years of comparison, between-class inequality increased by approximately the same amount. Similarly, stratification increased considerably, as $G_{b}$ got about four p.p. closer to $G_{B P}$ during the $1990 \mathrm{~s}$. This period encompasses the end of high inflation, in 1994, as well as the transition to neoliberalism. Therefore, if neoliberalism did not imply an overall increase of inequality as big as in other countries, it did reshape it with both an increase of class inequality and a sharper demarcation of class positions. From the 2000s onwards, on the other hand, both within- and between-class inequality fell, with a concomitant decrease of stratification. This result is line with most of what the literature has indicated (Hoffmann and Oliveira 2014, Souza and Carvalhaes 2014), and represents an important break with previous trends. This article contributes to understanding inequality Brazil as it explores this process in more detail, highlighting what it meant for class relations in Brazil, which fractions benefitted or not from it and showing its relation to the country's pattern of accumulation.

The components of the decomposition, seen on a group-by-group basis (the size, within-group concentration, relative income, mean rank and overlapping of each fraction), reveal that there were losses for most of the popular classes during the 1990s, followed by nuanced gains afterwards. These comprise a class structure with smaller shares of more vulnerable positions, as well as closing income gaps for some groups. These gains are, however, tempered by an almost-unchanging position of workers vis-à-vis capitalists. Only professional workers really lost relative income, rank and status. In other words, relations between different groups of workers changed, but their position to capital was much more stable.

\section{[FIGURE 4]}

The dimension that (alongside within-group concentration) changed the most was the class structure, i.e. the population-share of each fraction. As seen in Figure 4, the formal and informal low-skilled working class changed considerably, with approximately 10 p.p. swings between trough and peak. 
Apart from this, the only other two relevant developments are the smaller increases of professional workers and pensioners (approximately 2-4 p.p.).

Informality, an important dimension of labour precarisation, reached its peak in 2002 (41\% of the population) and then decreased sharply, reaching $30 \%$ in $2013 .{ }^{12}$ As its corollary, the formal working class would only return to its population-share of 1992 (39\%) in 2007, having reached a nadir of 34\% in 1999 at the height of neoliberalism. The rise of labour informality can thus be seen as the main driver of the increase of class inequality during the 1990s, and a major dimension of the latter's decrease afterwards. This should not obfuscate, however, that in 2013 more than $30 \%$ were in the precarious class position of low-skilled, informal workers.

\section{[FIGURE 5]}

Within-groups income concentration (see Figure 5), if it did change throughout the whole period, followed a similar pattern for most classes (capitalists and pensioners were the outliers). Only the income of formal, low-skilled workers was substantially less concentrated than that of the whole population. It was always approximately ten points below the overall Gini, whereas the second lessunequal group (informal, low-skilled workers) was about five points below. Nevertheless the Gini of formal workers, at 0.40 , was still high: the OECD average coefficient of household disposable income, in 2014, was 0.32 (OECD 2016). This highlights how income inequality is a multifaceted phenomenon in Brazil, the decrease of which requires changes internal to each class fraction, in addition to their position vis-à-vis each other and transformations of the class structure as a whole.

Within-groups income concentration was stagnant or slightly decreasing during most of the 1990s, with some exceptions, and since the end of that decade fell for all but capitalists. The most relevant trends regard low-skilled workers and pensioners. The Gini of (formal and informal) low-skilled workers decreased two points between 1992 and 2003, and then a further five points until 2013. Rising MWs and the growth of relatively low-paid jobs are the most likely explanation of the latter, as pointed out by the literature in different contexts (Brito, Foguel and Kerstenetzky 2017). The concentration of the income of pensioners, in turn, fell staggeringly, by nine points. This was associated to greater 
pension coverage and also to rising MWs, which are used as the index for many low-value benefits (Orair and Gobetti 2010). Finally, the income of capitalists became more concentrated throughout the two decades, which suggests an ongoing concentration of capital.

\section{[FIGURE 6]}

Relative income - i.e. a group's mean income divided by overall mean household per capita incomewas much more stable (see Figure 6). During the 1990s, there were small gains of about 5\% for all privileged fractions (i.e. with mean income above unity), with the obverse holding for relatively-poor ones. Informal workers were the exception, but this is misleading as their number rose through the precarisation of formal workers. Afterwards, there was a partial inflection of these trends, albeit more nuanced.

Between 2003 and 2013, the main change was the loss of relative income for professional workers, of about 20\%. Capitalists did lose, but not substantially (6\%), whereas small employers were stable. This highlights how control over capital became a more efficacious means of climbing the social ladder, as compared to the possession of scarce skills. On the lower side, the $10 \%$ increase in the relative income of informal workers was noticeable, if counterbalanced by falling relative income for other underprivileged groups, such as the unemployed.

A counter-intuitive result was that the relative income of low-skilled, formal workers did not increase, even in face of a 70\% hike in the real MW between 2003 and 2013 (Ipeadata). ${ }^{13}$ The main reason was a strong compression of formal, low-skilled wages between one and two MWs: in 2003, 44\% of formal low-skilled workers gained more than two MWs, a value that fell to $31 \%$ in 2013 . This explains much of the de-concentration of the group's income, but also indicates that well-paid positions were not forthcoming during the decade. As seen above, this compression is an effect of regressive structural change, with the rise of low-productivity services. There is evidence that similar results were also in place throughout LAC, as Galiani et al. (2017) show that it was the greater relative demand for lowskilled labour, as opposed to a higher supply of professional labour, that explains falling wage premia for tertiary-educated workers during the $2000 \mathrm{~s}$ in the region. 


\section{[FIGURE 7]}

Mean ranks displayed even greater resilience, as clear evidence that there was no overhaul of class relations in Brazil (see Figure 7). What could be seen was an enduring social hierarchy, with the different class fractions neatly stacked atop each other. Small and large employers were stable during the 2000s, whereas low-skilled, formal workers dropped two points. This signals that formal employment had become slightly less a 'privilege of the dispossessed' than it used to be, and that the position of capitalists did not change. Only three fractions altered their mean rank by more than two points: besides unemployed households and workers for self-consumption, who fell considerably, professional workers lost three points. Once again, this indicates that the main changes during the 2000s were restricted to relations between workers, and that that profiting from the labour of others became relatively more important than controlling scarce skills.

\section{[FIGURE 8]}

Stratification confirms the previous analysis (see Figure 8): there was a clearer demarcation of class positions in the 1990s (seen through lower overlapping indices, which imply greater stratification) and a partial inflection afterwards, albeit restricted to different fractions of workers. Between 1992 and 2003, the overlapping coefficient of capitalists went from 0.32 to 0.24 , whilst that of small employers went from 0.66 to 0.61 and of professional workers from 0.55 to 0.52 . The overall measure of stratification, $G_{B} / G_{B P}$, increased from 0.58 to 0.61 (where 1 indicates perfect stratification, as opposed to $O_{h}$ ). Thus, the transition to neoliberalism in Brazil had the effect of normalising accumulation and reorganising class relations in ways that strengthened social hierarchies.

From 2003 to 2013, on the other hand, overall stratification $\left(G_{B} / G_{B P}\right)$ decreased from 0.61 to 0.59 , driven by changes within fractions of workers. Low-skilled, formal workers became less of a stratum, increasing their overlapping coefficient from 0.84 to 0.88 . Professional workers lost the most distinction, however, as their overlapping coefficient rose from 0.52 to 0.59 - an increase of almost 15\%. ${ }^{14}$ Therefore, distinctions between different categories of workers grew more blurred throughout 
the decade, reducing overall class inequality. At the same, capitalists remained a clear stratum, and small employers became even more demarcated. This latter point, which stands in opposition to the developments for professional workers, supports the argument that the decline in inequality that took place under the PT governments did not confront capital, the possession of which became a stronger guarantee of social standing, but only relations between workers.

An overall assessment of the movements of class inequality can now be offered. The 1990s saw an increase of class inequality, driven by informalisation and greater returns to capital and other privileged class fractions, as well as higher class stratification. Within-group concentration fell slightly towards the end of the decade and faster during the 2000 s, when class inequality also fell. The main drivers of this were labour formalisation and narrower income gaps between professional and informal workers, as well as greater pension coverage. It should be highlighted that these conclusions - that the shifts in the distribution of income were restricted to developments amongst workers, whereas capital-based income was preserved — are not contradicted, but rather reinforced, by tax-returns data.

\section{THE EXHAUSTION OF THE GROWTH AND REDISTRIBUTION PROCESS}

The final element to be demonstrated is how the 'inside-out miracle' exhausted itself in deteriorating the country's insertion into the world market and stoking inflation. As shown in Figure 9, the current account and the balance-of-trade in goods both peaked in 2006, with respective surpluses of US\$ 13 and 45 billion, and then underwent a steady period of decline. Only a constant influx of capital, upwards of US\$ 70 billion in most years after 2009, prevented a deterioration of foreign solvency conditions. Although the balance-of-trade in goods remained moderately positive for the remaining of the period, the post-2006 increase in the value of exports was almost solely due to price changes, as the volume index oscillated 5\% around its 2006 level until 2014 (Ipeadata). Imports, on the other hand, increase in volume by almost $90 \%$ between 2006 and 2013. These problems thus predate the beginning of the world crisis, although they would be compounded by the latter.

[FIGURE 9] 
This deterioration was a result of the regressive structural change caused by the cumulative causation mechanism described in this article, which was enabled by a policy framework that curtailed public and private investment, had an overvalued exchange rate (see section 3), and, furthermore, had no consistent policy to upgrade the productive structure. Although several industrial policy initiatives were launched during the PT governments, the largest of which was the Greater Brazil Programme (Programa Brazil Maior-PBM) introduced in 2011, they had three fundamental shortcomings: lack of sectoral selectivity, no consistent focus on innovation, and a strong reliance on tax exemptions and subsidies as the main policy instruments (for a review, see Arbix et al. 2017). PBM, for example, considered no less than 19 sectors to be priorities, and actually gave greater assistance to less innovative sectors, as they were more labour-intensive and could hence potentially help maintain high employment levels (the shortcomings of subsidies as an instrument were analysed in section 3). In fact, to the extent that there was sectoral selectivity, it was designed to maintain the country's current comparative advantages by stimulating the internationalisation of existing 'national champions' (Boito Jr and Berringer 2014), which, with few exceptions, were not in technology- or research-intensive sectors (such as processed foods, mining and construction).

The Brazilian experience flies in the face of the recent literature on productive upgrading, which has highlighted that industrial policies, to be effective, must be structured around an inevitably selective vision or mission: it is inherently a matter of privileging certain sectors over others, directing resources to transform existing productive structures and defy present comparative advantages (Andreoni and Chang 2016, Mazzucato 2018). This is not to say that horizontal initiatives, such as infrastructure investments or developing industrial standards, are not required. The point is that such initiatives must be integrated in a plan that directs change, as opposed to distributing piecemeal subsidies across the board. Arbix (2017: 33) aptly summarised these problems: 'since its birth, the Brazilian [innovation] system has not been able to maintain constant flows of resources and has had a great difficulty in defining its focus and priorities, which is the root of the deleterious effects that spring from the 
pulverising of investment and the low technological ambitions of its agents. This fragmentation ... favours the development of knowledge without focus, priorities of concrete results.'

As a result, the domestic productive structure and the country's insertion into the global market deteriorated. As shown in section 3, employment grew mostly in domestic-orientated, low-productivity sectors, incapable of driving a development project. Furthermore, the composition of Brazilian exports by technological sophistication, following the classification Lall (2000) developed, regressed sharply. There was a steady decrease of high-, medium- and even low-technology manufactured goods, compensated for by a rise in resource-based manufactures and primary goods. Together, these latter two categories went from $51.9 \%$ of total Brazilian exports, in 2000, to $71.0 \%$, in 2013, whereas for LAC as a whole they went from $44.8 \%$ to $56.2 \%$ (data from WITS, World Bank 2018). Hence, if the re-primarisation of exports was a region-wide phenomenon, it was particularly acute in Brazil, heightening the country's dependence on the international price and demand for commodities (see also Nassif, Feijó and Araújo 2015).

Meanwhile, the imports bill was highly rigid, concentrated as it was in intermediate and capital goods: throughout the whole period they respectively accounted for about $70 \%$ and $15 \%$ of total imports (data from WITS, World Bank 2018). In particular, imports were concentrated in sectors with very few domestic substitutes — such as fertilisers, chemical goods and electronic machinery-leading to a low price-elasticity and a high income-elasticity of the demand for imports (Santos et al. 2015). This implies that rising imports were not the effect of growing purchasing power directly buying foreign goods. They were, rather, an indirect effect of rising household income, mediated by a growingly deficient productive structure that, to provide the goods demanded by those at the bottom, had to resort to imports. Which means that fast growth, in the conditions Brazil faced towards the end of the analysed period, would need to bring about either an increase of exports or a substitution of imports, under the penalty of being unsustainable.

Maintaining a competitive real exchange rate was a necessary, if far from sufficient condition, to revert the regressive structural change and improve the balance-of-trade, but it would create inflationary 
pressures. ${ }^{15}$ After a low point of $3.1 \%$ in 2006 , inflation rose and since 2008 remained consistently above the official target of $4.5 \%$, sometimes above the ceiling of $6.5 \%$ (see Figure 10 ). Studies about the nature of inflation in Brazil during the 2000s have shown that excessive demand was not, per se, an important cause. Wage gains - through their impact on the costs of services-were amongst the main determinants, on the other hand (Giovannetti and Carvalho 2015, Santos et al. 2016a). Figure 10 shows the IPCA inflation index, highlighting the contribution of services. Since the mid-2006, when wage gains picked up and the structural change deepened, services were consistently above the overall index, confirming the proposed link.

\section{[FIGURE 10]}

In sum, as shown throughout the article Brazil had, from 2003 until 2013, a GDP per capita growth rate and a decrease of income inequality close to the LAC average, but with lower investment rates and a stronger deterioration of the technological intensity of its exports. After 2013, the country entered a deep social, economic and political crisis, whilst most of the region slid into a milder stagnation. This indicates the presence of both international and domestic factors in explaining the rise and fall of the region's economies, although with Brazilian specificities that made the country underperform.

It is beyond the scope of this article to identify the precise timing and individual contribution of all domestic and international factors that produced these particularly negative results in Brazil. What has been demonstrated is that during the 'success-period' of 2003-2013 there were growing fragilities in Brazil synthesised in a regressive structural change, which were stronger than in the rest of the region - and largely the result of the very process of growth and redistribution. The key issue is that these fragilities would make the country less capable of facing a downturn in global economic conditions, which would inevitably come at some point, or domestic-generated instabilities.

Economic and political factors, both domestic and international, thus combined to generate the post2013 crisis in Brazil, but its severity can only be fully understood by taking into account the preceding accumulation of fragilities - in turn a result of the proposed cumulative causation process in a policy framework that did not provide medium-term conditions for development. In particular, the framework 
had structurally low investment rates, notwithstanding the short-lived and comparatively unimpressive spurt of 2007-2010; reduced the price-competitiveness of domestic tradables due to an overvalued currency used as an inflation-controlling mechanism; lacked a coherent industrial policy to shift the productive structure towards higher-value-added, technology-intensive sectors; and did not attack deeper sources of inequality. If these structural conditions do not identify the immediate causes of the crisis, they explain the growing inefficacy of the development strategy, which would hence necessarily exhaust itself in the medium-term.

\section{Conclusion}

This article has taken an integrated approach to income inequality and capital accumulation in Brazil, analysing the 1992-2013 period with a focus on the last decade. It has contributed by showing the interconnection between the pattern of accumulation and income distribution, better specifying their class dimension. Based on this, it has shown how the growth and redistribution phase of the 2000s created growing fragilities that the policy framework in place could not overcome.

It was first shown how income-boosting policies, in the form of MW hikes and greater social-security benefits, changed the demand pattern and thus initiated a feedback mechanism that drove growth between 2003 and 2013. Higher income at the bottom of the pyramid raised the demand for wagegoods, and hence for low-skilled workers to produce them. This led to labour formalisation and higher wages for these workers, feeding back on the cycle. The article then demonstrated the centrality of these developments in explaining the changes to income inequality during the $2000 \mathrm{~s}$. It also showed how the decline of inequality that did take place was limited, as the relative income of capitalists was not affected and control over capital became a more efficacious form of climbing the social ladder visà-vis the control over scarce skills. Finally, it showed how this pattern of accumulation and redistribution was unsustainable in the medium term, as it was coterminous with a regressive structural change that increased the weight of low-productivity services sectors. Given an overall policy framework that maintained high interest rates, curtailed investment, appreciated the real exchange rate 
and had no consistent industrial policy, this generated growing trade deficits, lower productivity, a reprimarisation of exports and spurred cost-push inflation. The stagnation of export volumes after 2006 and their decreasing technological content were key developments.

This combined approach to inequality and accumulation in Brazil highlights two limitations that would not be observable if the processes were taken separately. The fall of inequality exhausted itself not in its own terms, but rather as it created constraints in terms of inflation and the international insertion of the economy. Furthermore, the whole process was dependent on the commodities boom. The latter guaranteed, whilst it lasted, medium-term solvency to the balance-of-trade and provided foreign reserves. This allowed for the exchange rate to appreciate as an inflation-controlling mechanism, in spite of this being a process with a clearly limited time frame. Taken together, the restricted character of the redistribution and the dependence on the commodities boom show the limitations of the changes Brazil underwent.

This does not mean that wages had grown too much, that social benefits had to be cut or that contractionary fiscal policies were called for. Quite the contrary, to continue to have growth and redistribution it would be necessary to attack deeper sources of inequality, whilst simultaneously developing novel strategies to increase productivity and promote progressive structural change. For this, more transformative actions had to be adopted, capable of reducing inequality beyond the labour market and transforming the international insertion of the economy. This would, however, necessarily go against powerful, established interests in the Brazilian economy. This analysis suggests that nonconfrontational policies can indeed lead to a pro-poor, equality-driven growth pattern in the short term, but embarking on a sustainable path to development requires a bolder and multi-dimensional approach, with a corresponding political strategy. 


\section{ENDNOTES}

${ }^{1}$ For an analysis saying that these policies were technically possible, but not politically feasible under the conciliatory strategy of the PT, see Loureiro and Saad-Filho (2019).

2 The values are deflated by the INPC.

${ }^{3}$ Labour informality also decreased substantially, as analysed in section 4 .

${ }^{4}$ The international price of commodities was also a positive determinant, mainly as it relaxed financing conditions.

${ }^{5}$ Mixed income is counted as profits.

${ }^{6}$ The fact that, especially until 2010 , changes to the sectoral composition of the economy were the main driver of the higher wage-share (Martins 2017) is also relevant to understand how, in spite of such higher share, the profit rate vacillated without a clear trajectory until 2010 (Marquetti, Hoff and Miebach 2017). This also helps explains how, as shown in the next section, the income of capitalists was basically stable over the whole period.

7 Considering Argentina, Bolivia, Brazil, Chile, Colombia, Costa Rica, Ecuador, El Salvador, Guatemala, Honduras, Mexico, Nicaragua, Panama, Paraguay, Peru and Uruguay.

${ }^{8}$ See Brito et al. (2017) for the impact of the MW, and Souza and Carvalhaes (2014) for the distribution of education.

${ }^{9}$ For other studies of class inequality in Brazil, see Figueiredo Santos (2005) and Souza and Carvalhaes (2014).

${ }^{10}$ In case the groups are malformed enough strata, so that their mean rank varies inversely with their income, the term can actually be negative. This only happens if the groups are not really strata.

${ }^{11}$ See Castellano et al. (2016) for a comparison.

${ }^{12}$ See Figure 5 and Figure 6 for a comparison of the distribution of income for formal and informal low-skilled workers.

${ }^{13}$ Their real income increased by about $50 \%$. 
${ }^{14}$ It is beyond the scope of this work to investigate what social and identitarian repercussions this loss of status and privilege might have implicated for the traditional middle-class in Brazil. It is, nevertheless, a demonstration that this group was the one that gained the least during the 2000s and increasingly had to share spaces with the ascending lower classes, perhaps suggesting some measure of déclassement.

15 The appreciation of the real discussed in section 3, which just about doubled the currency's real value, was hardly sustainable. Reverting this appreciation would have a limited effect on the balanceof-trade, however, given the low price-elasticity of Brazilian exports and imports (Santos et al. 2015), and reverting the regressive structural change required much more than guaranteeing the pricecompetitiveness of domestic tradable sectors (Andreoni and Chang 2016). 


\section{REFERENCES}

Andreoni, A. \& H.-J. Chang. 2016. Industrial policy and the future of manufacturing. Economia $e$ Politica Industriale, vol. 43, no. 4, 491-502.

Arbix, G. 2017. À espera da mão invisível. Outra vez? Novos Estudos CEBRAP, vol. 2017, no. junho, 29-40.

Arbix, G., M.S. Salerno, G. Amaral \& L.M. Lins. 2017. Avanços, equívocos e instabilidade das políticas de inovação no Brasil. Novos Estudos CEBRAP, vol. 36, no. 3, 9-27.

Azevedo, J.P., G. Inchaust \& V. Sanfelice. 2013. Decomposing the Recent Inequality Decline in Latin America. World Bank Policy Research Working Papers, vol. 6715, 1-26.

Barboza, R.M. 2015. Taxa de juros e mecanismos de transmissão da política monetária no Brasil. Revista de Economia Política, vol. 35, no. 1, 133-155.

BCB. 2017. Séries Temporais. SGS. https://www3.bcb.gov.br/sgspub/ (last accessed 21/10/2016).

Boito Jr, A. \& T. Berringer. 2014. Social Classes, Neodevelopmentalism, and Brazilian Foreign Policy under Presidents Lula and Dilma. Latin American Perspectives, vol. 41, no. 5, 94-109.

Brito, A., M. Foguel \& C. Kerstenetzky. 2017. The contribution of minimum wage valorization policy to the decline in household income inequality in Brazil: A decomposition approach. Journal of Post Keynesian Economics, vol. 40, no. 4, 540-575.

Carvalho, L. 2018. Valsa brasileira: do boom ao caos econômico. São Paulo, Todavia.

Castellano, R., R. Manna \& G. Punzo. 2016. Income inequality between overlapping and stratification: a longitudinal analysis of personal earnings in France and Italy. International Review of Applied Economics, vol. 30, no. 5, 567-590.

Fevereiro, J.B. \& P. Passoni. 2018. Growth accounting in the age of global-value chains: A demand side perspective for Brazil in the period of 2000-2015. Proceedings of the 26th International Input-Output Conference, 1-19.

Figueiredo Santos, J.A. 2005. Uma classificação socioeconômica para o Brasil. Revista Brasileira de Ciências Sociais, vol. 10, no. 58, 27-45. 
Galiani, S., G. Cruces, P. Acosta \& L.C. Gasparini. 2017. Educational Upgrading and Returns to Skills in Latin America: Evidence from a Supply-Demand Framework. National Bureau of Economic Research Working Paper Series, vol. No. 24015.

Giovannetti, L.F. \& L. Carvalho. 2015. Distribuição de renda, mudança estrutural e inflação de serviços no Brasil. Anais do Encontro da ANPEC, vol. 43, 1-20.

Gobetti, S.W. \& R. Orair. 2015. Política fiscal em perspectiva: o ciclo de 16 anos (1999-2014). Revista de Economia Contemporânea, vol. 19, no. 3, 417-447.

Hoffmann, R. \& R.B. Oliveira. 2014. The Evolution of Income Distribution in Brazil in the Agricultural and the Non-agricultural Sectors. World Journal of Agricultural Research, vol. 2, no. $5,192-204$.

Kaltenbrunner, A. \& J.P. Painceira. 2017. The Impossible Trinity: Inflation Targeting, Exchange Rate Management and Open Capital Accounts in Emerging Economies. Development and Change, vol. 48 , no. $3,452-480$.

Krause, C., R. Balbim \& V.C. Lima Neto. 2013. Minha casa minha vida, nosso crescimento: Onde fica a política habitacional? Textos para discussão do IPEA, vol. 1853, 1-50.

Lall, S. 2000. The Technological Structure and Performance of Developing Country Manufactured Exports, 1985 - 98. Oxford Development Studies, vol. 28, no. 3, 337-369.

Lavinas, L. 2015. A financeirização da política social: o caso brasileiro. Politika, vol. 2, 35-51.

Loureiro, P.M. \& A. Saad-Filho. 2019. The Limits of Pragmatism: The Rise and Fall of the Brazilian Workers' Party (2002-2016). Latin American Perspectives, vol. 46, no. 1, 66-84.

Marquetti, A., C. Hoff \& A. Miebach. 2017. Lucratividade e Distribuição: A Origem Econômica da Crise Política Brasileira. In XXII Encontro Nacional de Economia Política. Campinas: SEP.

Martins, G.K. 2017. Lucratividade, desenvolvimento técnico e distribuição funcional: uma análise da economia brasileira entre 2000 e 2013. In XXII Encontro Nacional de Economia Politica. Campinas: SEP. 
Mazzucato, M. 2018. Mission-oriented innovation policies: challenges and opportunities. Industrial and Corporate Change, vol. 27, no. 5, 803-815.

Medeiros, C.A. \& M.R.V.P. Cintra. 2015. Impacto da ascensão chinesa sobre os países latinoamericanos. Revista de Economia Política, vol. 35, no. 1, 28-42.

Medeiros, M. \& F.A. Castro. 2018. A composição da renda no topo da distribuição. Economia $e$ Sociedade, vol. 27, no. 2, 577-605.

Morais, L. \& A. Saad-Filho. 2011. Da economia política à política econômica: o novodesenvolvimentismo e o governo Lula. Revista de economia politica, vol. 31, no. 4, 507-527.

Nassif, A., C.A. Feijó \& E.C. Araújo. 2015. Structural change and economic development: is Brazil catching up or falling behind? Cambridge Journal of Economics, vol. 39, no. 5, 1307-1332.

OECD. 2016. Income inequality remains high in the face of weak recovery. Income Inequality update, vol. November 2016.

Orair, R. 2016. Investimento público no Brasil: trajetória e relações com o regime fiscal. Textos para discussão do IPEA, vol. 2215, 1-44.

Orair, R.O. \& S.W. Gobetti. 2010. Governo gastador ou transferidor? Um macrodiagnóstico das despesas federais no período 2002 a 2010. In Brasil em Desenvolvimento, v. 1, ed. IPEA, 87111. Brasília, IPEA.

Pyatt, G. 1976. On the Interpretation and Disaggregation of Gini Coefficients. The Economic Journal, vol. 86 , no. $342,243-255$.

Rugitsky, F. 2017. The rise and fall of the Braziilian economy (2004-2015): the economic antimiracle. FEA/USP Working Paper Series, vol. 2017, no. 29, 1-44.

Santos, C.H.M., C.R. Amitrano, M.C.C. Pires, S.C. Carvalho, E. Ferreira, F.H.d.A. Esteves, K.Z.J. Yannick \& L.d.S. Lima. 2016a. A natureza da inflação de serviços no Brasil: 1999-2014. Textos para discussão do IPEA, vol. 2169, 1-48.

Santos, C.H.M., A.G. Cieplinski, D. Pimental \& G. Behring. 2015. Por que a elasticidade-câmbio das importações é baixa no brasil? Evidências a partir das desagregações das importações por categorias de uso. Textos para discussão do IPEA, vol. 2046, 1-34. 
Santos, C.H.M., A.D.M. Modenesi, G. Squeff, L. Vasconcelos, M. Mora, T. Fernandes, T. Moraes, R. Summa \& J. Braga. 2016b. Revisitando a dinâmica trimestral do investimento no Brasil: 19962012. Revista de Economia Política, vol. 36, no. 1, 190-213.

Serrano, F. \& R. Summa. 2015. Aggregate demand and the slowdown of Brazilian economic growth in 2011-2014. Nova Economia, vol. 25, no. especial, 803-833.

Simson, R. 2018. Mapping recent inequality trends in developing countries. International Inequalities Institute (III-LSE) Working Papers, vol. 24, 1-54.

Souza, P.H.G.F. \& F.A.O. Carvalhaes. 2014. Estrutura de classes, educação e queda da desigualdade de renda (2002-2011). Dados, vol. 57, no. 1, 101-128.

World Bank. 2018. World Integrated Trade Solution (WITS/UNCOMTRADE). http://wits.worldbank.org (last accessed 30/11/2018).

Wright, E.O. 2000. Class counts. Cambridge, Cambridge University Press.

Yitzhaki, S. \& E. Schechtman. 2013. The Gini methodology: A primer on a statistical methodology. New York, Springer.

\section{APPENDIX: DEFINITION OF THE CLASS TYPOLOGY}

For instrumental reasons, the understanding of class is restricted to the relations of production into which an individual is inserted, insofar as captured in large surveys. Three dimensions are considered: ownership of capital (conversely, the need to sell one's labour power), command over scarce skills (conversely, being restricted to low-skilled occupations), and basic protection by the prevailing labour laws (i.e. the formality of the employment relation). Those not in active employment were classified as unemployed, inactive or pensioners, as appropriate. These dimensions account for the main classbased determinations of income, and hence inequality, and provide a link to the pattern of accumulation previously analysed. 
More specifically, using data from the National Household Sampling Survey (PNAD), from 1992 to 2013, the identification of class positions is based on four main variables: position in the occupation, skill level required for the occupation, number of employed workers (for employers) and access to social security. Position in the occupation is classified into four categories: employers, self-employed, formal waged employees, informal waged employees and workers for self-consumption or nonremunerated. The occupations were classified according to their skill level they required, into either professional or low-skilled ones. For individuals classified as employers, a distinction was made in terms of the number of employees, differentiating between those who employed more or less than ten workers. Finally, access to social-security was considered positive when either the person was in a formal employment relation, which guarantees state pensions, or when she contributed to a private pension scheme. Taken together, these variables define the following positions:

1. Large employers: employers of more than 11 employees, the most privileged position based on the command over large amounts of labour;

2. Small employers: employers of 10 or less employees, an intermediate position based on commanding a smaller amount of labour;

3. Professional workers: employees or self-employed workers in high-skilled occupations. They are also in an intermediate position, as they must sell their labour power, but can do so at more advantageous conditions given their command over scarce skills. Alongside small employers, these are the 'contradictory class positions' Wright (2000) discusses;

4. Low-skilled, formal workers: formal employees, or self-employed workers that contribute to social security, in low-skilled occupations. This group has to sell their labour power without the bargaining power that scarce skills offer, but are covered by basic labour laws and social protection;

5. Low-skilled, informal workers: informal employees, or self-employed workers that do not contribute to social security, in low-skilled occupations. These are the most precarious workers, 
who do not command scarce skills and are not even covered by the prevailing labour legislation;

6. Self-consumption workers: workers who produce for self-consumption or do not receive monetary income from their activity;

7. The unemployed and inactive: those classified as looking for jobs but unable to find them during the reference period, or not looking for jobs and not receiving pensions;

8. Pensioners: former workers who receive private or state pensions. 
Figure 1 Mechanisms of the growth, redistribution and regressive structural change process

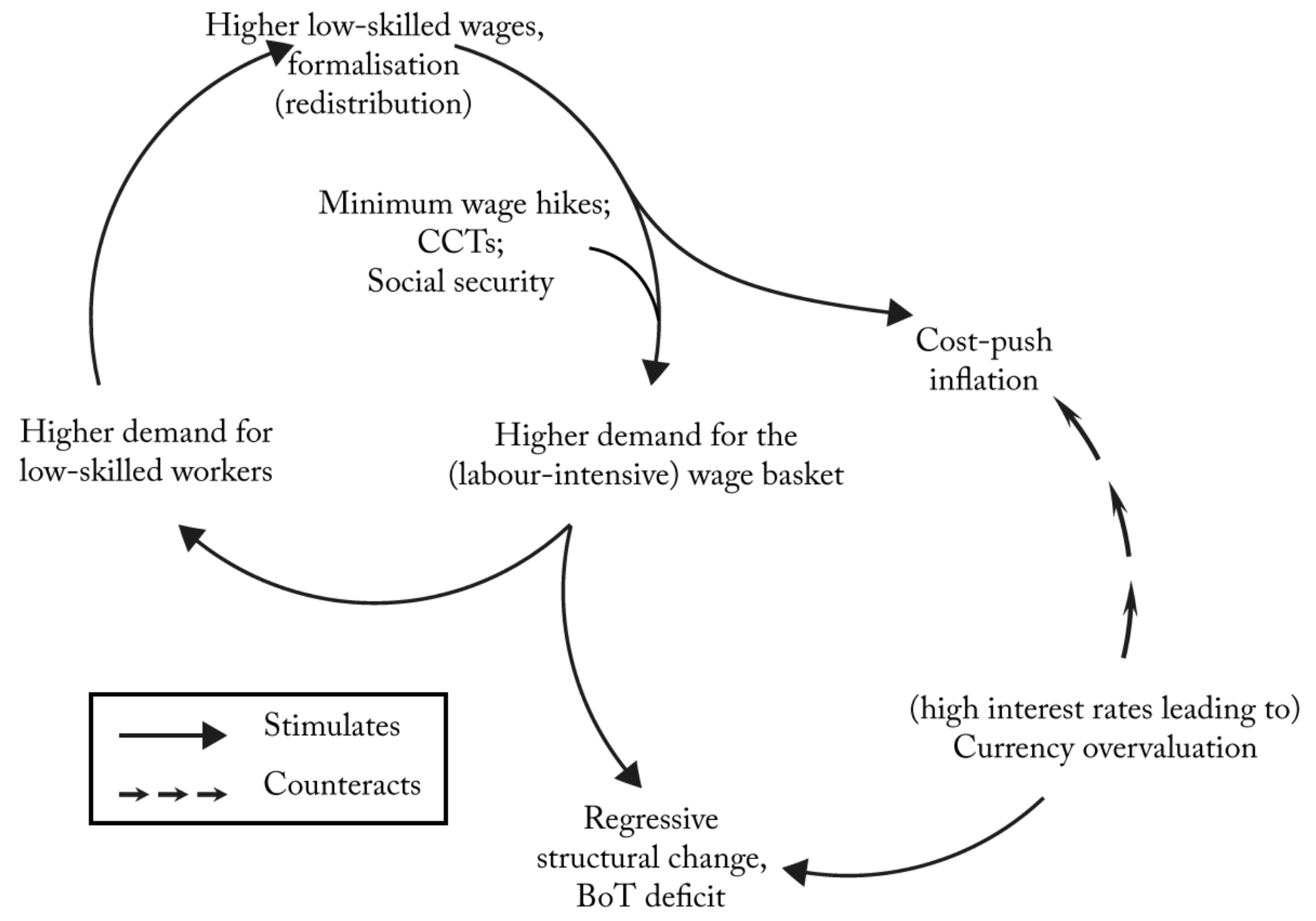

Source: Prepared by the author. 
Figure 2 Contribution of different sources of demand to the growth rate of GDP in Brazil, 2001-2015. Absolute contributions net of their impact on imports.

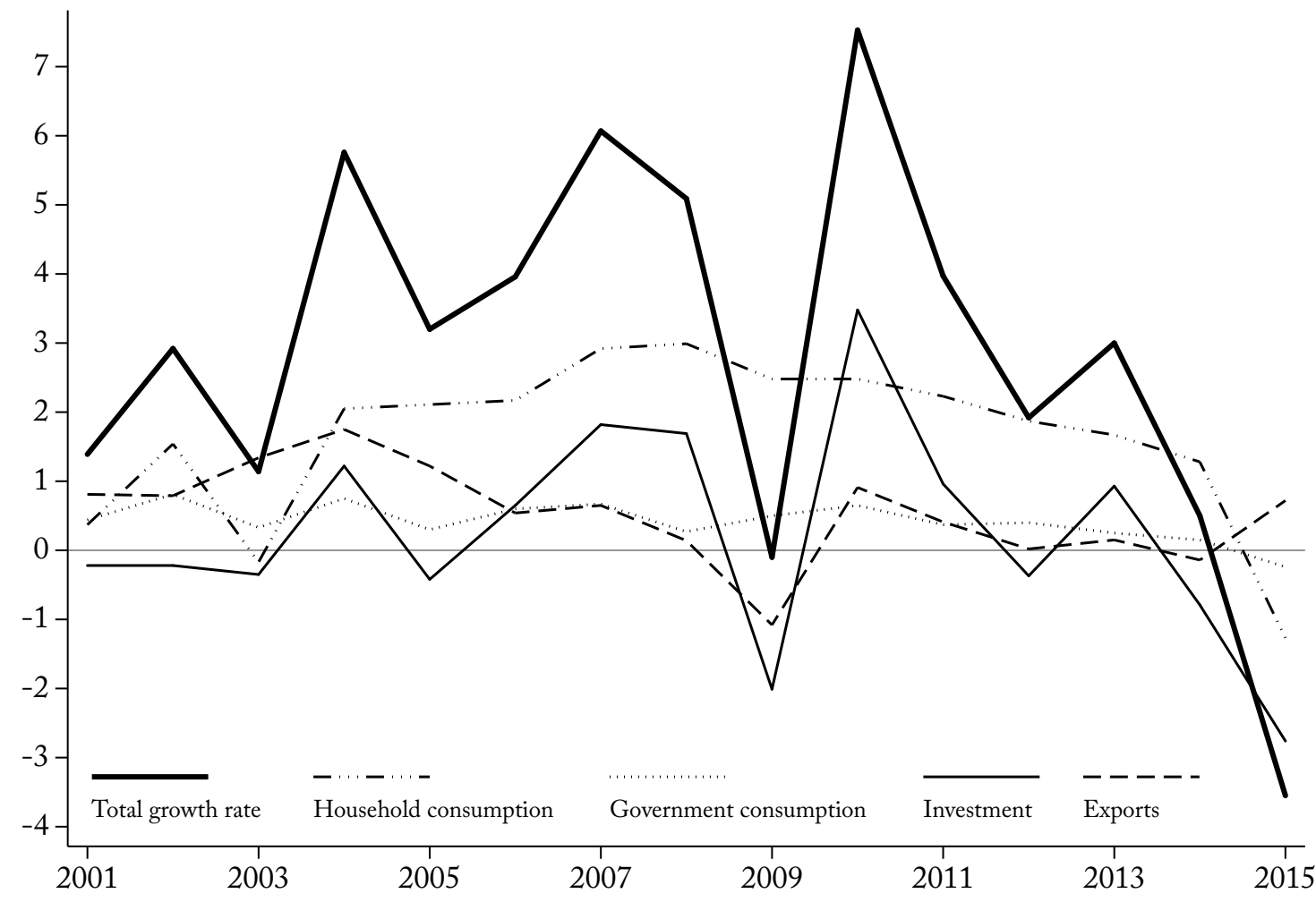

Source: Prepared by the authors based on data by Fevereiro and Passoni (2018). 
Figure 3 Gini coefficient of household per capita income in Brazil and decomposition by class positions $\left(G, G_{W O}, G_{B}\right), 1992-2013$

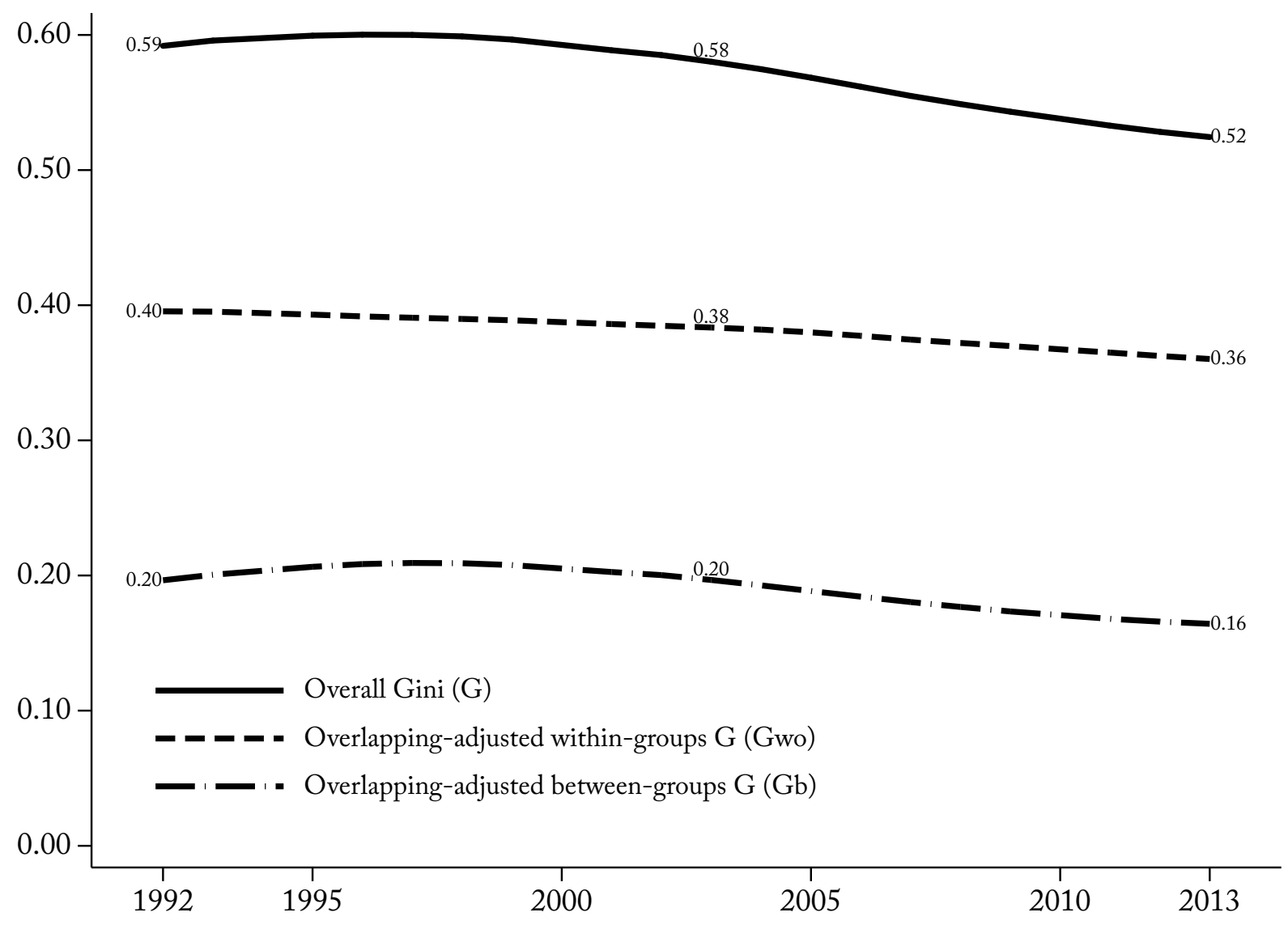

Note: Smoothed values shown for years 1992, 2003 and 2013; LOWESS smoothing applied.

Source: Prepared by the author based on data from PNAD/IBGE. 
Figure 4 Population-share $\left(p_{h}\right)$ of class fractions in Brazil, 1992-2013

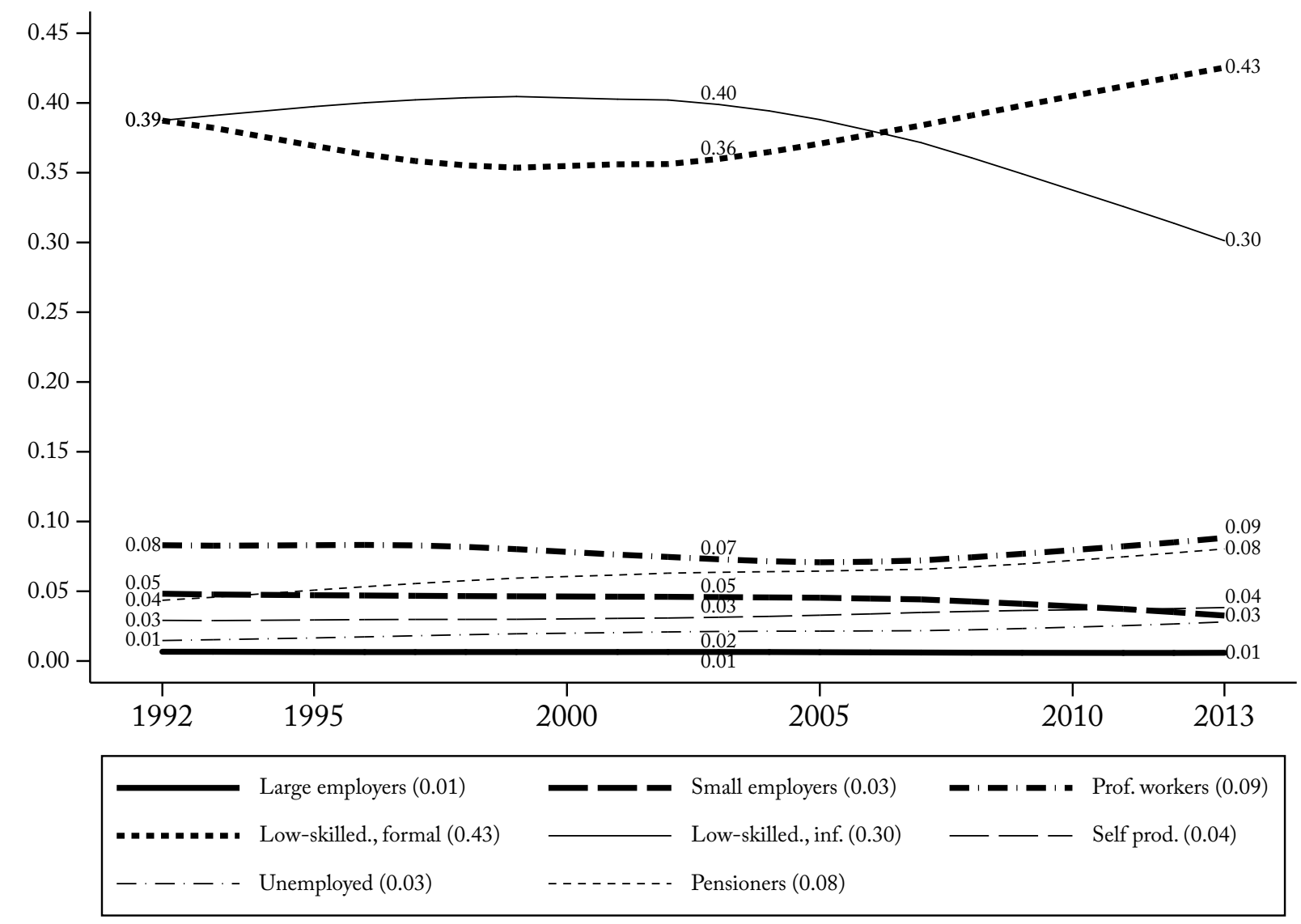

Note: Smoothed values shown for years 1992, 2003 and 2013; 2013 values shown in legend to help identify classes; LOWESS smoothing applied. The same applies for Figure 5 through Figure 8.

Source: Prepared by the author based on data from PNAD/IBGE. 
Figure 5 Gini coefficients of intra-group income concentration $\left(G_{h}\right)$ for the decomposition of household per capita income by class positions in Brazil, 1992-2013

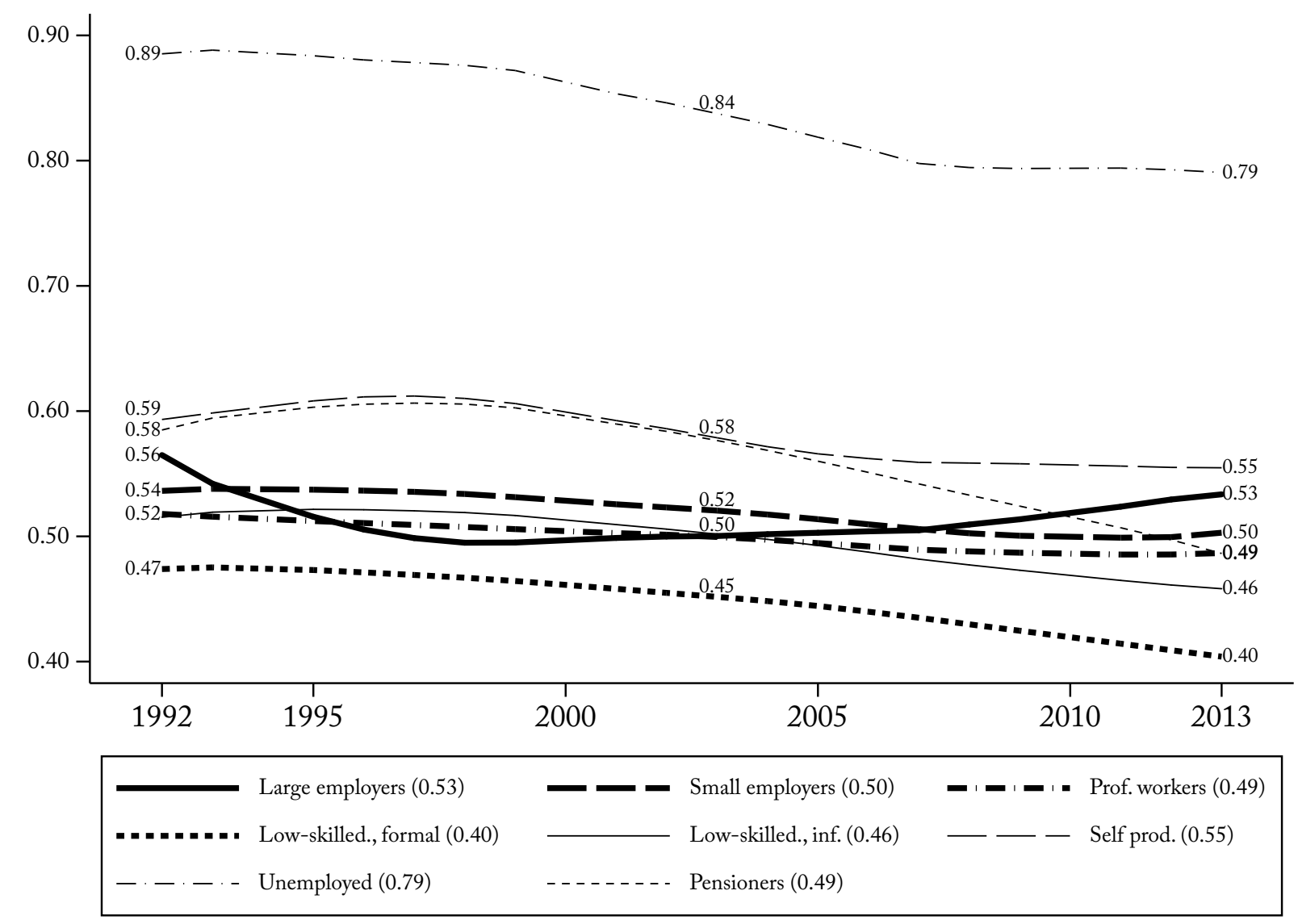

Notes and source: see Figure 4. 
Figure 6 Relative household per capita income $\left(\eta_{h}\right)$ of class positions in Brazil, 1992-2013

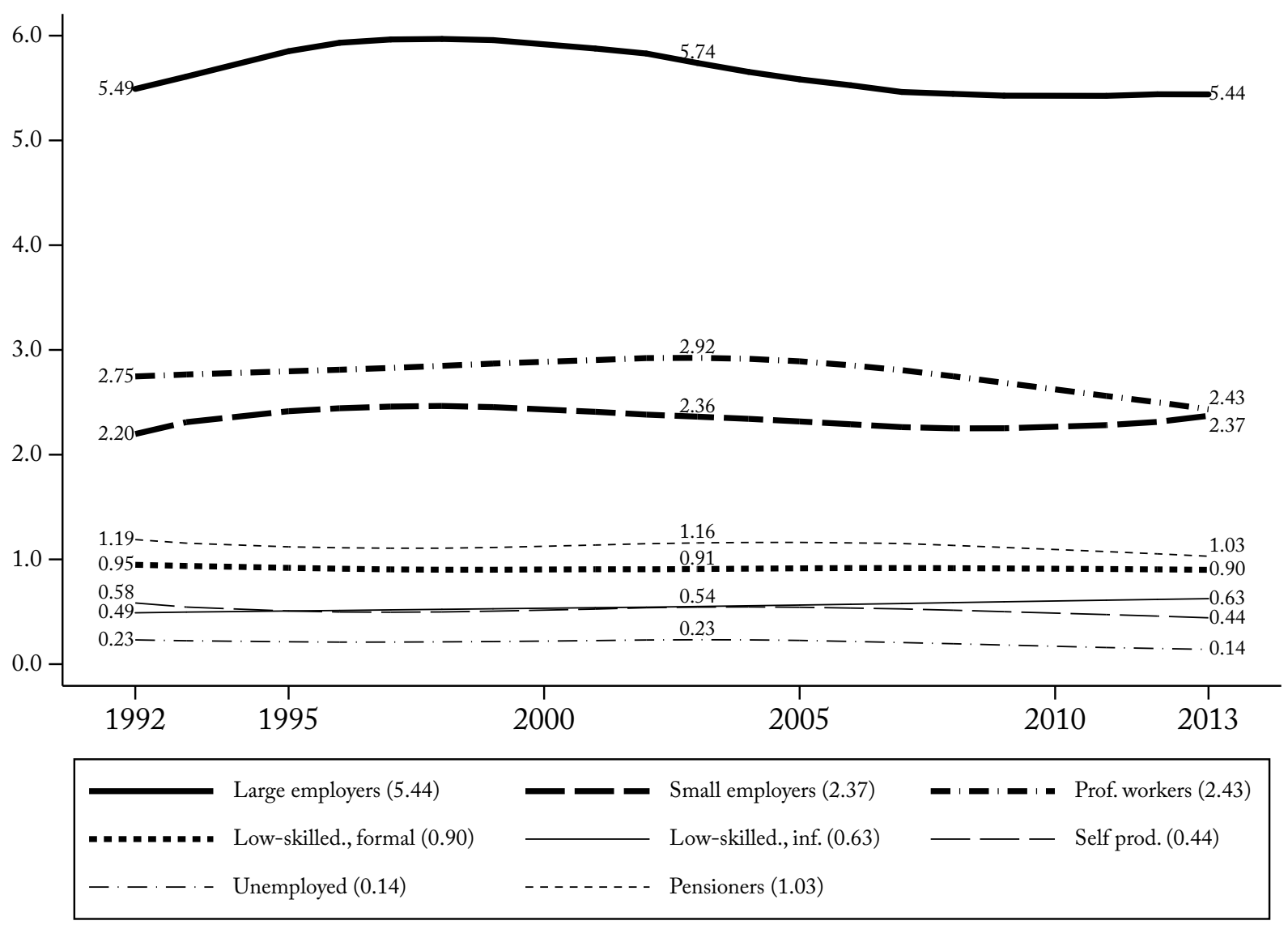

Notes and source: see Figure 4. 
Figure 7 Mean rank of class positions $\left(F_{h}\right)$ according to household per capita income in Brazil, 19922013

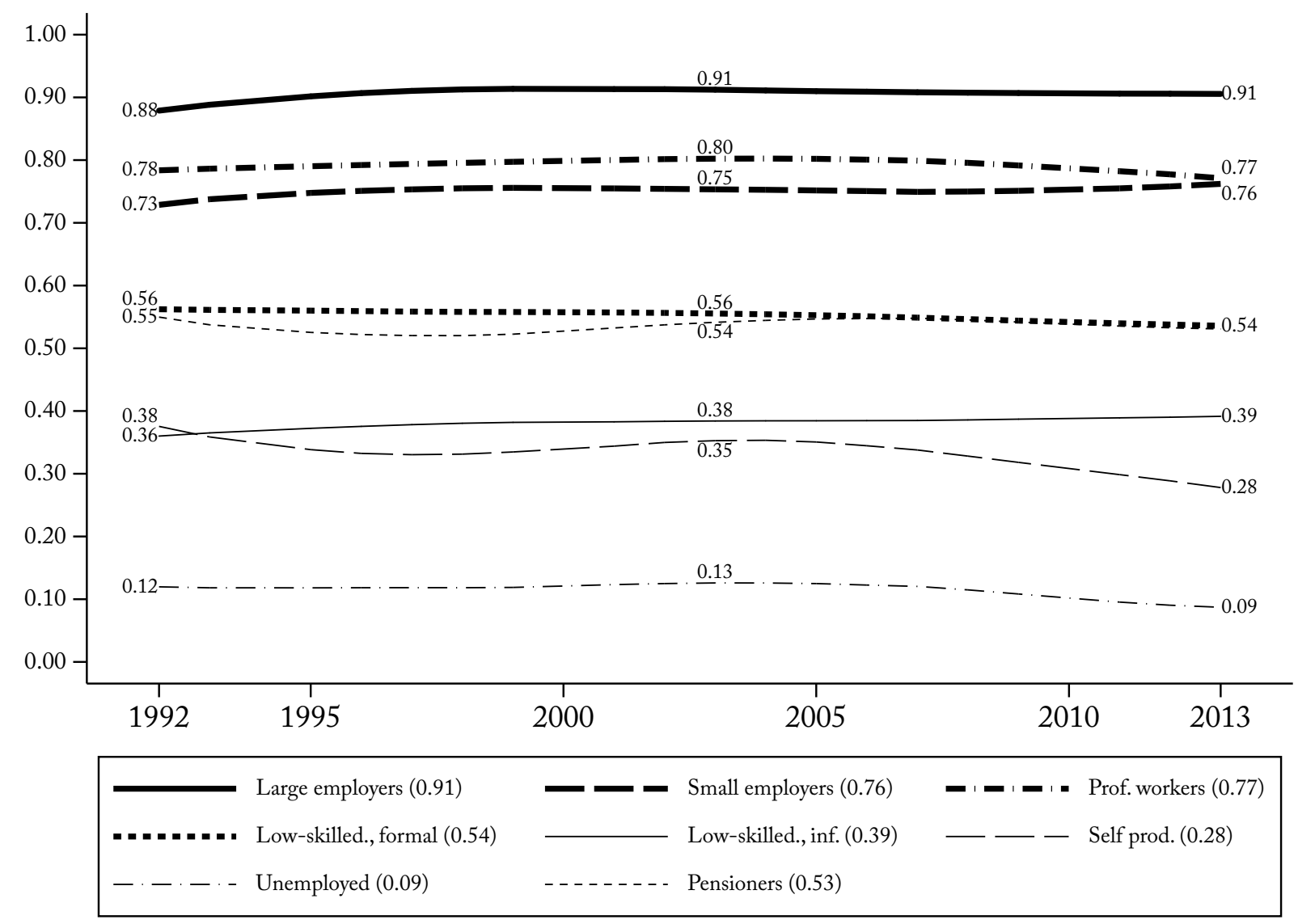

Notes and source: see Figure 4. 
Figure 8 Overlapping index of class positions $\left(O_{h}\right)$ in the decomposition of household per capita income in Brazil, 1992-2013

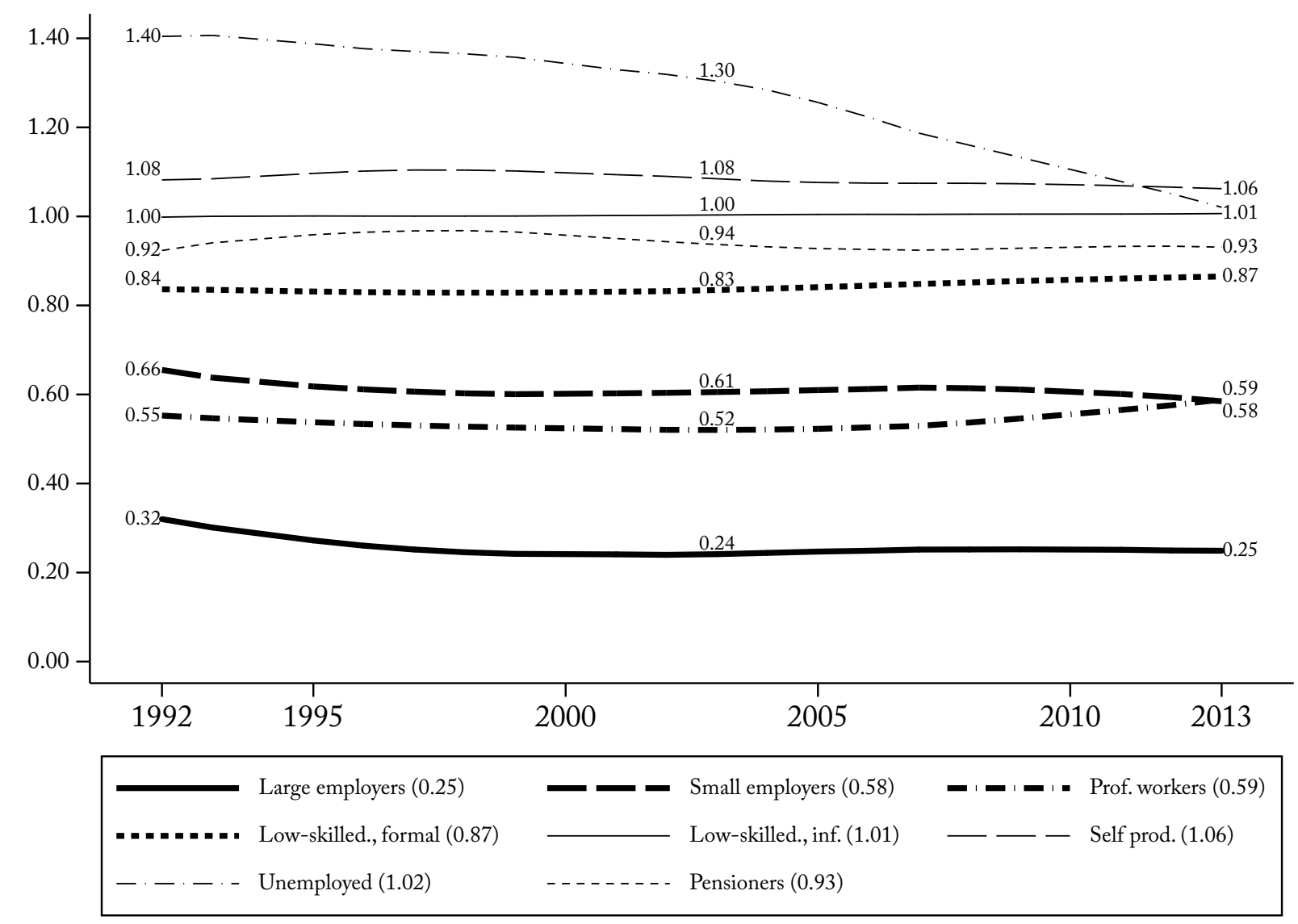

Notes and source: see Figure 4. 
Figure 9 Select balance-of-payments accounts for Brazil, 2001-2015. Net values in US\$ billion

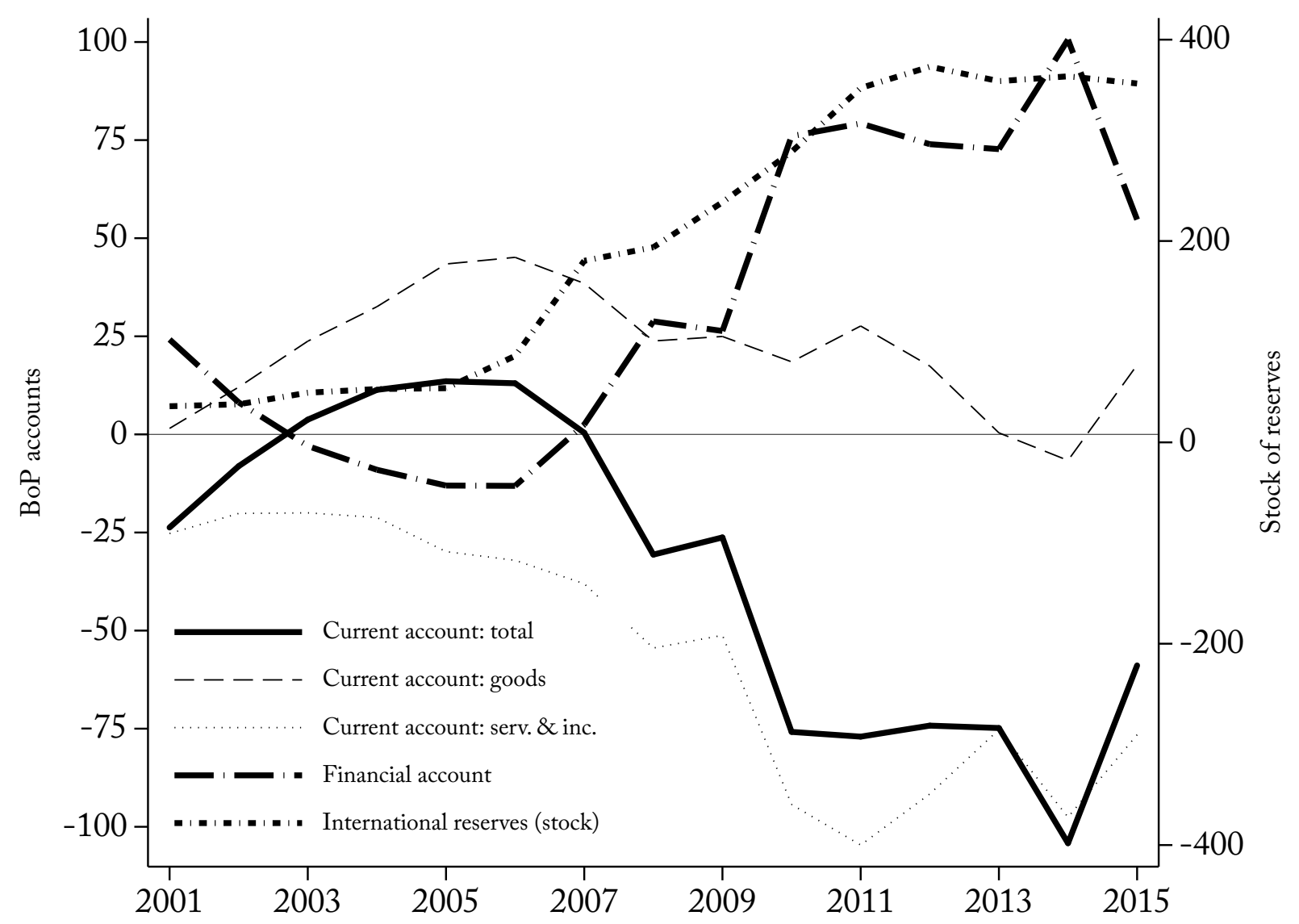

Source: Prepared by the author based on data from Ipeadata. 
Figure 10 Inflation (IPCA index, 12-months) in Brazil, decomposed by the contribution of its services and non-services elements, Jan/2002-Dec/2015

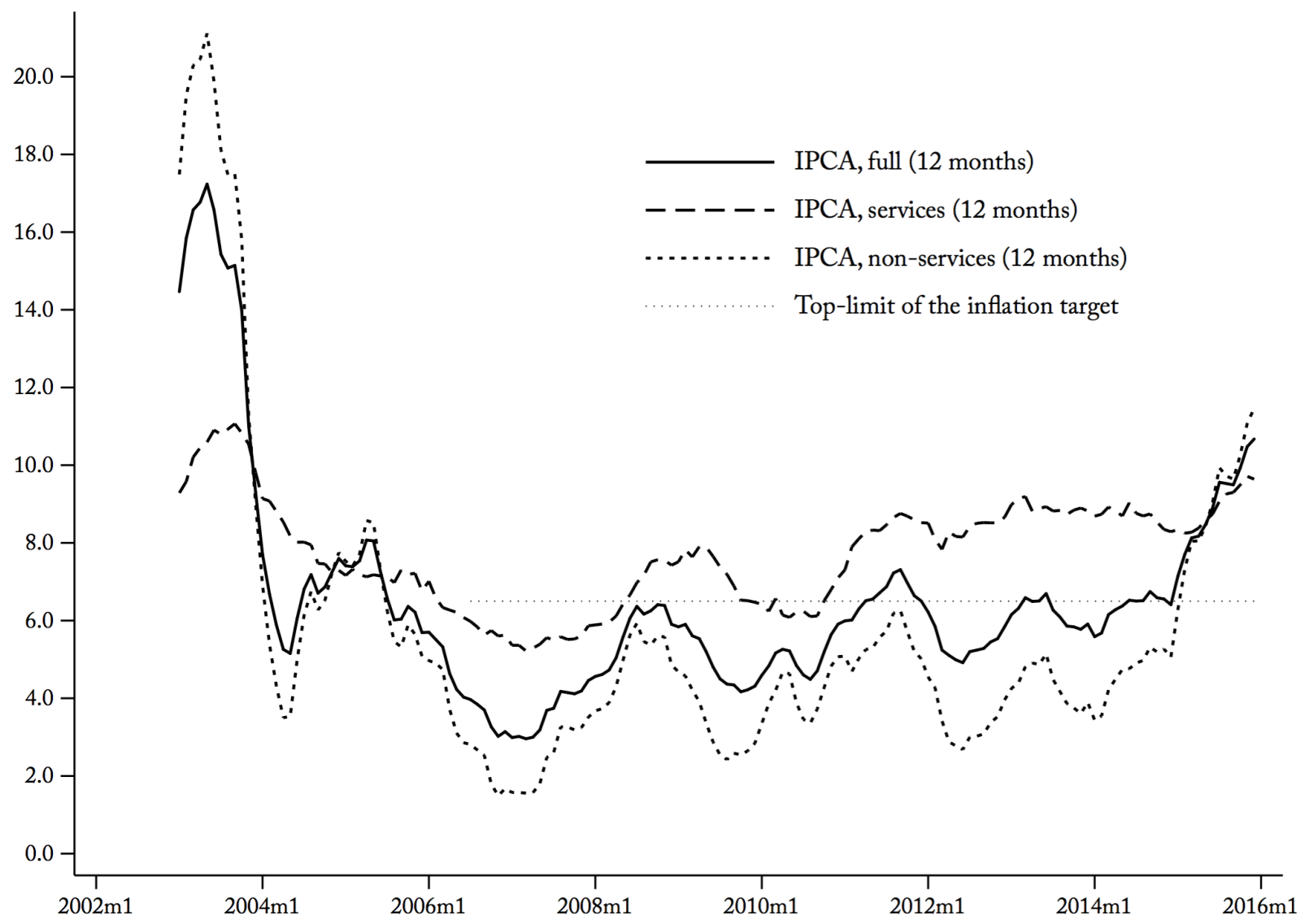

Source: Prepared by the author based on data from IBGE. 
Table 1 Average contribution of different sources of demand to the growth rate of GDP in Brazil for selected sub-periods, 2003-2013. Estimates net of their impact on imports.

\begin{tabular}{|c|c|c|c|c|c|}
\hline Period & $\begin{array}{c}\text { Private } \\
\text { consumption } \\
(\% \text { of total })\end{array}$ & $\begin{array}{l}\text { Government } \\
\text { consumption } \\
(\% \text { of total })\end{array}$ & $\begin{array}{l}\text { Investment } \\
(\% \text { of total })\end{array}$ & $\begin{array}{c}\text { Exports } \\
\text { (\% of total) }\end{array}$ & $\begin{array}{l}\text { Total GDP } \\
\text { growth rate } \\
(\% \text { of total }) \\
\end{array}$ \\
\hline $2003-2005$ & $\begin{array}{c}1.3 \\
(39.5 \%)\end{array}$ & $\begin{array}{c}0.5 \\
(13.7 \%)\end{array}$ & $\begin{array}{c}0.2 \\
(4.5 \%)\end{array}$ & $\begin{array}{c}1.4 \\
(42.7 \%)\end{array}$ & $\begin{array}{c}3.4 \\
(100 \%)\end{array}$ \\
\hline $2006-2013$ & $\begin{array}{c}2.4 \\
(59.8 \%)\end{array}$ & $\begin{array}{c}0.5 \\
(11.8 \%)\end{array}$ & $\begin{array}{c}0.9 \\
(22.7 \%)\end{array}$ & $\begin{array}{c}0.2 \\
(5.5 \%)\end{array}$ & $\begin{array}{c}3.9 \\
(100 \%)\end{array}$ \\
\hline
\end{tabular}

Source: Prepared by the authors based on data by Fevereiro and Passoni (2018).

Note: These estimates use input-output data to discount the impact of the different sources of demand on imports, which is a supply-side variable, and are hence a more appropriate way of analysing the demand-side drivers of growth. See Fevereiro and Passoni (2018) for details and a comparison with the standard methodology. 
Table 2 Net employment generation, wages and labour productivity for sectors that generated more than 500 thousand net jobs between 2003 and 2013, Brazil

\begin{tabular}{|c|c|c|c|c|c|}
\hline Sector & $\begin{array}{l}\text { Thousands of net jobs } \\
\text { created, 2003-2013 } \\
\text { (\% of total) }\end{array}$ & $\begin{array}{c}\text { Relative } \\
\text { average } \\
\text { wages, } \\
2013 \\
\end{array}$ & $\begin{array}{c}\text { Labour } \\
\text { productivity, }{ }^{1} 2013 \\
\text { (relative } \\
\text { productivity) }\end{array}$ & $\begin{array}{l}\text { Difference in } \\
\text { labour } \\
\text { productivity, } \\
\text { 2003-2013 }\end{array}$ & $\begin{array}{c}\text { Wage-share of } \\
\text { value added, }{ }^{2} \\
2013\end{array}$ \\
\hline $\begin{array}{l}\text { Food and } \\
\text { beverages }\end{array}$ & $\begin{array}{c}812 \\
(4.3)\end{array}$ & 1.17 & $\begin{array}{c}20.8 \\
(0.98)\end{array}$ & 5.0 & 0.602 \\
\hline $\begin{array}{l}\text { Machinery and } \\
\text { equipment }\end{array}$ & $\begin{array}{c}521 \\
(2.8)\end{array}$ & 1.63 & $\begin{array}{l}27.5 \\
(1.3)\end{array}$ & -10.7 & 0.637 \\
\hline Construction & $\begin{array}{l}3,156 \\
(16.8)\end{array}$ & 0.65 & $\begin{array}{c}15.8 \\
(0.74)\end{array}$ & 3.8 & 0.443 \\
\hline Sales & $\begin{array}{l}3,310 \\
(17.6)\end{array}$ & 0.69 & $\begin{array}{c}15.8 \\
(0.74)\end{array}$ & 6.6 & 0.469 \\
\hline $\begin{array}{l}\text { Transport and } \\
\text { storage }\end{array}$ & $\begin{array}{l}1,009 \\
(5.4)\end{array}$ & 1.06 & $\begin{array}{c}21 \\
(0.99)\end{array}$ & 7.2 & 0.541 \\
\hline Lodging services & $\begin{array}{c}764 \\
(4.1)\end{array}$ & 0.4 & $\begin{array}{c}10.2 \\
(0.48)\end{array}$ & 4.4 & 0.424 \\
\hline $\begin{array}{l}\text { Services provided } \\
\text { to businesses }\end{array}$ & $\begin{array}{l}2,658 \\
(14.2)\end{array}$ & 1.15 & $\begin{array}{c}24.9 \\
(1.17)\end{array}$ & 0.2 & 0.495 \\
\hline $\begin{array}{l}\text { For-profit } \\
\text { education }\end{array}$ & $\begin{array}{l}1,083 \\
(5.8)\end{array}$ & 0.95 & $\begin{array}{c}11.7 \\
(0.55)\end{array}$ & -6.3 & 0.877 \\
\hline For-profit health & $\begin{array}{l}955 \\
(5.1)\end{array}$ & 0.85 & $\begin{array}{l}19.1 \\
(0.9)\end{array}$ & -0.5 & 0.480 \\
\hline $\begin{array}{l}\text { Services provided } \\
\text { to families }\end{array}$ & $\begin{array}{l}1,140 \\
(6.1)\end{array}$ & 0.58 & $\begin{array}{c}9.3 \\
(0.44)\end{array}$ & 1.2 & 0.661 \\
\hline Total private & $\begin{array}{r}15,409 \\
(82.1)\end{array}$ & 0.78 & $\begin{array}{c}16.3 \\
(0.77)\end{array}$ & 3.6 & 0.511 \\
\hline Public education & $\begin{array}{l}1,229 \\
(6.6)\end{array}$ & 2.01 & $\begin{array}{c}22.6 \\
(1.06)\end{array}$ & 4.9 & 0.956 \\
\hline Public health & $\begin{array}{c}700 \\
(3.7)\end{array}$ & 2.24 & $\begin{array}{c}25.2 \\
(1.19)\end{array}$ & 1.3 & 0.955 \\
\hline $\begin{array}{l}\text { Public } \\
\text { administration }\end{array}$ & $\begin{array}{l}1,285 \\
(6.9)\end{array}$ & 3.17 & $\begin{array}{c}39.0 \\
(1.84)\end{array}$ & 2.2 & 0.873 \\
\hline Grand total & $\begin{array}{c}18,767 \\
(100)\end{array}$ & 1 & $\begin{array}{c}21.2 \\
(1)\end{array}$ & 3.7 & 0.506 \\
\hline
\end{tabular}

Source: Prepared by the author based on National Accounts data

Notes: ${ }^{1}$ : labour productivity in thousands of 2003 Brazilian reais per worker per year, deflated by the implicit GDP deflator. Wages include benefits. ${ }^{2}$ : The wage-share of value added excludes mixed income (i.e. mixed income and profits comprise the profit-share). 